\title{
Development of Electrochemical Platform Based on Carbon Nanotubes Decorated with Zirconium Oxide Nanoparticles for Determination of Nebivolol
}

\author{
Mirela Sadiković and Biljana Nigović* \\ University of Zagreb, Faculty of Pharmacy and Biochemistry, A. Kovacica 1, 10000 Zagreb, Croatia \\ *E-mail: bnigovic@ pharma.hr
}

doi: $10.20964 / 2017.10 .10$

Received: 23 June 2017 / Accepted: 19 July 2017 / Published: 12 September 2017

\begin{abstract}
Electrochemical sensor based on carbon nanotubes decorated with zirconium oxide nanoparticles was developed for the determination of nebivolol at the potential of $+1.05 \mathrm{~V}$ ( $v s$. $\mathrm{Ag} / \mathrm{AgCl}$ ). Nanomaterials were dispersed in an anionic polymer and deposited by simple one-step casting method on glassy carbon electrode. Scanning electron microscopy and energy dispersive X-ray spectroscopy were used to study the surface morphology and structure characterization of deposited film. The sensor has a strongly improved sensitivity $\left(9.29 \times 10^{-6} \mu \mathrm{A} \mathrm{M}^{-1}\right)$. The electrocatalytical peak current of nebivolol shows a linear response from $100 \mathrm{nM}$ to $10 \mathrm{mM}$ with detection limit of $12 \mathrm{nM}$. Low-cost analysis of drug in serum samples was carried out after adsorption of nebivolol at the nanocomposite using differential pulse voltammetry. In comparison with HPLC method, the electrochemical method ensures faster and simpler quantification of nebivolol in pharmaceutical samples.
\end{abstract}

Keywords: Nebivolol, Zirconium oxide nanoparticles, Carbon nanotubes, Differential-pulse voltammetry, Nafion

\section{FULL TEXT}

(C) 2017 The Authors. Published by ESG (www.electrochemsci.org). This article is an open access article distributed under the terms and conditions of the Creative Commons Attribution license (http://creativecommons.org/licenses/by/4.0/). 